\title{
The Anointed Son, The Hired Gun, and the Chai Wala: Enemies and Insults in Politicians' Tweets in the Run-Up to the 2019 Indian General Elections
}

\author{
A'ndre Gonawela \\ University of Michigan \\ andregon@umich.edu \\ Dina Ahmad \\ University of Michigan \\ diahmad@umich.edu
}

\author{
Reeshma Kumar \\ University of Michigan \\ kumarre@umich.edu \\ Ramgopal Chandrasekaran \\ University of Michigan \\ ramgopal@umich.edu
}

\author{
Udit Thawani \\ University of Michigan \\ uthawani@umich.edu \\ Dr. Joyojeet Pal \\ University of Michigan \\ joyojeet@umich.edu
}

\begin{abstract}
This study seeks to assess the prevalence, style, and impact of antagonistic messaging on Twitter in the two years preceding the 2019 Indian General Elections. Focusing on the leadership of the two key parties - the ruling BJP, with Prime Minister Narendra Modi and party president Amit Shah, and the opposition INC's president Rahul Gandhi, we attempt to understand how the politicians sought to portray each other on Twitter, and how their followers reacted to these characterizations, through the lens of Murray Edelman's work on the 'Political Enemy'. By thematically coding tweets and quantitatively analyzing their retweets, we find that negative tweets by and large are significantly more popular for all three politicians, and that the opposition leader allocated a significantly larger proportion of his tweets to attacks. We conclude that while leaders in power and those in opposition may take different stances with messaging, Twitter as a social networking site can perpetuate the online reward for attacking behavior.
\end{abstract}

\section{Introduction}

Narendra Modi's electoral victory in 2014 was the beginning of what some termed was a new surge of populist-nationalism in India, timed alongside the ascent of several politicians who used populist planks, including the Philippines' Rodrigo Duterte, the US' Donald Trump, and Brazil's Jair Bolsonaro. Many of these politicians were noted for their direct online outreach, often in preference to mainstream media [1] [2] [3]. Social media has become a means of unmediated outreach, freeing politicians from conventions of mainstream media discourse and allowing them to personalize their online presence and build communities around the alternative narratives of nation-hoods they proposed [6]. While these leaders adopted a unique form of nationalist speech, it is increasingly true that politicians from across the spectrum have begun to personalize their Twitter and engage in rhetorical attacks, as we have seen with Democrats in the 2018 US Midterm Elections [4].

Unlike Modi, the Indian National Congress party's Rahul Gandhi (Modi's main opponent) did not use Twitter at all in 2014, and started a serious online presence after his electoral loss. He started a Twitter account using a formal third-person style, naming his account @OfficeOfRG. However, by 2017, he changed his handle to '@RahulGandhi', and as a series of reports showed, moved to a more witty, casual tone, using more Indian languages, directly attacking Modi, and in the process, dramatically increased his social media following [5]. Notwithstanding Gandhi's rise on social media, Modi and the BJP maintained supremacy online with the highest number of leaders who had individual followings in the millions, and a dedicated layer of active, ideologically-driven online supporters. Backed by a well-funded campaign, and solid on-theground organization, the BJP came back to power with an even larger majority in the 2019 General Election.

With most key leaders using social media aggressively, fights between individuals have publicly played out online, and campaigns in India have centered on leaders rather than on ideology. There has been much commentary on Modi's own candidatecentric campaign, a first for the right wing BJP party, and the near ubiquitous media presence has moved India closer to personality-centric elections, despite the party-driven parliamentary system [6]. Twitter arguably accentuates this, as candidates directly reach diverse audiences without filtration by mainstream media.

Social media has enabled a new performativity in online conversations, in which divisiveness is often 
driven by the acrimonious content of individual politicians' messaging [5]. A range of studies have aimed to understand the tone and content of online political speech, particularly using sentiment analyses of the populations receiving political messages [7]. In this study, we use in-depth interpretive analysis of the content of tweets from the three key leaders in the election - Narendra Modi and Amit Shah, the leaders of the BJP, and Rahul Gandhi of the INC, in the more than two years preceding the 2019 General Elections, to understand the tenor of messaging both during and prior to an election cycle. In particular, we aim to assess the impact of the differing styles of negative rhetoric, through the number of retweets and favorites that such tweets elicit. This study serves as a follow-up to Gonawela et al's work on the usage of negative rhetoric by populist-nationalist politicians, which included a study of Narendra Modi's 2014 campaign [8]. In this study, we dive deeper into the Indian elections, focusing particularly on how negative messaging is received by audiences, and consider what styles of negative messaging are more impactful for incumbents and challengers, and why. We use Murray Edelman's theory of the 'Political Enemy' as we analyze the findings, in our efforts to better understand the value of Twitter as a means of political framing.

\section{Political Enemies, Incivility, and Worlds}

Murray Edelman presented the notion of a 'political spectacle', a reality created by the politician for their like-minded audience through rhetorical means [4]. In essence, the spectacle is an artificial creation, built through media messaging, working to persuade an audience of the leader's perspectives. Moreover, the audience subjected to the spectacle is an 'exclusive' group, that would subscribe to the leader's worldview. In this study, we discuss a component of Edelman's proposition - the 'political enemy'.

Edelman proposes that, whereas a political 'opponent' may be respectable, a political 'enemy' is innately dishonorable. An opponent is branded as an enemy not simply because of their policy positions, but because they are inherently immoral, their fundamental character imbued with traits that motivate their bad actions. In turn, they undermine the virtue of society, in contrast to the political protagonist who works to advance this virtue. Importantly, these immoralities are not readily apparent - rather, these traits can be created by the attacker through rhetoric. Framing an opponent as symbolic of moral ills expands the stakes, and increases the number of invested actors. In essence, the political enemy necessitates the spectacle by exposing the risks it presents to society [9].
We see the political enemy being present in the communication strategies of national campaigns. This is well seen in populist movements, as de la Torre assessed the campaign of Ecuadorian politician Abdalá Bucaram. Bucaram worked (through the lens of 'populist moralism') to show his opponents to be 'evil', expediting 'difficult social processes' [10].

Similarly, Gonawela et al. discuss the proliferation of the 'political enemy' in the tweets of several populist-nationalist political leaders, which include US President Donald Trump and Indian Prime Minister Narendra Modi [8]. Specifically, Gonawela asserts that the usage of antagonism, and particularly the casting of these leaders' opponents as 'political enemies' has reward on Twitter. Potts also draws on Edelman in her assessment of the Trump's communications and asserted that it was impossible to 'Make America Great Again' without considering the Democrats as enemies - Trump framed Clinton as representing all that made America horrible, posing a contrast with himself [11].

Both studies assert that the use of incivility through insults, 'bullying', and disparagements proved popular to Trump's Twitter audiences, which call to question the popularity of incivility across a broader scope in the political sphere. Gervais discusses the role of incivility used by the 'political elite' in motivating anger within certain populations by asserting that counterattitudinal (the expression of views that contradict one's own beliefs) incivility stimulates anger as well as 'combative partisanship' within the populations receiving the elite messaging [12]. Gervais has also argued that the use of incivility by the elite leads to the adoption of that extreme rhetoric by the populations exposed - and in essence, serves as an 'imitation' of those politicians [13]. Moreover, the rise of political incivility on social media can upend discourse around singular issues itself [14]. Polarization arises as a direct result, to the point where constructive discourse is impossible.

However, another strain of thought regarding the creation of alternate realities that parallels Edelman's spectacle, concerns the use of the Dostoevskian 'carnival'. Bakhtin states that the carnival is a created environment, in which 'official authorities and cultures' are gone, and there is 'free and familiar contact' between everyone, regardless of social position [15] [16].

Janack takes Bakhtin's theory and assesses it through the lens of the gubernatorial campaign of Jesse Ventura [16]. Ventura's campaign was carnivalesque, as it featured outlandish and 'indecent' language which was popular with his audience. Through this style, Ventura was able to position himself as a 'carnival fool' striving to oppose the 'political elite'. 
Badarneh, in the context of Arab political humor, dives into the 'the crowning', discussing Bakhtin's five steps: first, the leader is glorified; second, they are mocked; third, they are parodied; fourth, they are humiliated with innuendoes; fifth, they're 'decrowned', in a move that is backed by 'the people'. According to Badarneh, such humor is an alternate reality, outside of the constraints of present society [17].

\section{Twitter as a Political Tool}

There has been much research on Twitter and its organizational strengths for politicians. This is well seen in the example of US President Barack Obama, who was able to adeptly employ both Twitter and Facebook in his 2008 Election campaign [19]. Obama leveraged the mediums to tout the notion that he was 'connected' with the 'people', creating an image that his followers were engaged in the campaign through the social media connection, which then fostered mass organization within this network [19] [21]. Metzgar \& Maruggi asserts that the 'lack of hierarchy', an inherent characteristic of social media, is the key to success on the platforms. However, social media success requires effective messages, as it's a 'tool' of dissemination, not a substitute for communication strategy [22].

Jungherr identifies the use of Twitter by political entities as a way for political actors to relay their respective platforms, in addition to influencing the manner by which traditional news outlets frame their candidacies [23]. Indeed, Twitter, and social media overall, is a politician's 'direct link' to their audience, enabling them to bypass such filtered mediums and communicate their views and arguments completely [24]. Moreover, with the use of social media, 'news' can be created by these politicians [25] [26] [27]. In essence, this behavior motivates the creation of the 'Twitter Agenda' (what Twitter users discuss), and the subsequent disparity between that and the 'Public Agenda' (the issues that actual civilians care about) that is governed by the most active of users [28].

Social media enables politicians to brand their online personality. Meeks suggested that campaign rhetoric on Twitter during the 2012 Senate elections typified a 'personal, intimate, and conversational' mode of rhetoric [29]. This heightened level of interaction and personality is a new phenomenon, brought about by the attributes of Twitter, and an important part of modern electoral campaigns. Paralleling this, Ceccobelli found that references to a political actor's persona were prominent on Facebook. However, in the same study, Ceccobelli found that Facebook was not conducive to antagonistic messaging [30]. Borah, in her study of the 2008 and 2012 US Presidential Elections, also made a similar observation
- Mitt Romney's attacks were less popular than Barack Obama's enthusiasm [31]. This finding is qualified by her citation of Benoit, which suggests that challengers attack more than incumbents (even if the attacks weren't as popular), due to the incumbent already having an advantage [32] [31].

However, Twitter seems to present a different story. Brian Ott's commentary on Donald Trump's ascendancy to the presidency provides a centerpiece through which we can assess the attributes of Twitter that correspond to antagonistic messaging, and more specifically, political incivility [33]. First, as Ott states, Twitter is both informal and impersonal, leading to a 'coarseness' in the type of rhetoric that can emanate on the platform, due to the lack of consequence to the actor. Moreover, Ott cites the work of Thelwall et al., who have argued that Twitter fosters negativity, which is clearly more popular than positivity on the platform [34]. This accordingly leads to leaders like Donald Trump [33]. Rossini et al. reinforce this notion through their study of the 2014 US Gubernatorial Elections; 'persuasive' and 'attack messaging' were more prevalent on Twitter, and they cite Stromer-Galley and Kreiss in suggesting that Twitter is most effective with 'viral-messaging' -- and antagonistic messaging is more likely to become viral on Twitter [35] [36] [37].

In the Indian context, scholars have observed the effective usage of Twitter by Narendra Modi in order to 'rebrand' himself, as he pivoted away from a controversial image as a regional nationalist leader to a more unifying, forward-thinking persona as a national candidate [38]. This rebranding on Twitter even took the form of selfies at times, as Modi sought to present himself as 'accessible', 'personal', and most importantly, 'modern' [39] [38]. Indeed, Modi's social media strategies parallel Barack Obama's campaigns, and is rooted in American-style tactics, which has in effect transformed the nature of campaigning in India [40]. However, as noted by scholars, Modi's Twitter use has been effective in part due to the nature of his online sarcasm, innuendoes, wordplay, and insults that have elicited significant online rewards [41][8].

\section{Methods}

We conducted this study through the use of a mixed-methods analysis, downloading the Englishlanguage tweets (via the Twitter Public API) from BJP Leaders@narendramodi and @AmitShah, as well as INC Leader@RahulGandhi from January 1 1, 2017 through March 28 ${ }^{\text {th }}, 2019$, the month immediately preceding the polling. Our goal was to capture tweets for the period just prior to the actual polling to avoid any effect of exit polls on politicians' online behavior. 
Each tweet was qualitatively categorized by a pair of coders according to five themes that sought to define varying tones of political rhetoric. Additionally, only English-language tweets were coded. Once the categorical coding was finished, quantitative analysis was done on the retweet and favorite rates of each category in an effort to assess popularity. Replies to a tweet were not generally assessed because they can be nuanced - they may include thanks and support, but they can also be dismissive or antagonistic. In comparison, retweets and likes usually signal some form of endorsement. Likes are a public affirmation of affinity to a tweet's message, while a retweet aims to spread the message to one's own following, which has significance in an electoral context. The themes used were based on prior work by Gonawela et al, which used a similar characterization of antagonistic messaging in political tweets [8].

\subsection{Selecting the Politicians}

The 2019 Indian General Elections proved to be a rematch of 2014, again pitting the BJP's incumbent Prime Minister Narendra Modi (the former Chief Minister of Gujarat) against INC Leader Rahul Gandhi (the heir to the Gandhi Dynasty) in the contest for the premiership. Therefore, we pulled tweets from their official accounts,@narendramodi and@RahulGandhi respectively. While Rahul Gandhi was the apparent prime ministerial candidate, he also was the official head of the INC. In contrast, Modi was not the official head of the party - rather, his deputy Amit Shah was. Therefore, we included @AmitShah's tweets, as we viewed Modi and Shah as a tag-team on Twitter.

\subsection{Themes}

This study builds on Gonawela et al.'s categorization of antagonistic messaging in political tweets based on the linguistic and contextual features of text objects. The current set of themes included 'Criticism', 'Insult', 'Wordplay', 'Humor and Sarcasm', and we added 'Regards' as a counterweight category ('Regards' were generally positively toned). Regards as a means of signaling amiability and thoughtfulness are part of a politician's outreach strategy and prior studies have shown that Indian politicians use casual messaging aimed at their constituents as a means of brand building rather than moving the agenda on a specific issue [38]. The theme categories are non-exclusive, thus a tweet can be both a criticism and contain wordplay. 'Criticism' and 'Insult' annotated tweets that were generally negative, whereas 'Regards' marked tweets that were positive [8].
4.2.1. Criticism. Criticism was defined as the expression of negative sentiments, targeted towards a particular person, group, or entity. Below, an example:

"The work done by the NDA Government for Amethi should have been done years ago. Sadly, it was not done. https://t.co/fnVjZs8Ur3" -@narendramodi, 3 March 2019

4.2.2. Insult. Insults were basically criticisms directed at a particular target's character, leaving aside policyonly criticisms. This theme is nested within the 'Criticism' theme - so all 'Insults' are also 'Criticisms'. Yet, a separate category is useful to understand the personal nature of attack. An example:

"Chandrababu Naidu has more faith in Prime
Minister of Pakistan rather than Prime Minister of
his own country and Indian Army. One should not
stoop so low for vote bank politics.
https://t.co/2MpKuDVaAn" -- @AmitShah, 4
February 2019

4.2.3. Wordplay. Wordplay was the use of performative rhetoric tactics that could include metaphors, idioms, puns, and alliteration. An example by @RahulGandhi:

"Startup India, Stand up India, Right turn India: but no jobs for the youth of India! https:/t.co/2EiQjdK9x6" -- @RahulGandhi, 14 June 2017

4.2.4. Humor and Sarcasm. Humor and Sarcasm denoted tweets that were intentionally tinged with comedic elements or attempts at humor, in addition to the usage of irony, mockery, parody, and statements where the 'intended meaning of the speaker is not the literal meaning.' An example by @ Rahul Gandhi:

Dear Mr Modi, Now that campaigning is over, hope you can spare some time for your part-time job as PM. Btw its been 1,654 days since u became PM. Still no press conference? Some pics from our Hyderabad PC today. Try one someday, it's fun having questions thrown at you! https://t.co/Tc3I1kLGBI -- @RahulGandhi, 12 May 2018

4.2.5. Regards. Regards refers to any tweet in which a particular person or entity is referred to with congratulations, condolences, gratitude, tributes, and greetings - all positive expressions. In general, regards will not intersect with other categories. An example: 
"India will be eternally grateful to Shri Manohar Parrikar for his tenure as our Defence Minister. When he was RM, India witnessed a series of decisions that enhanced India's security capacities, boosted indigenous defence production and bettered the lives of ex-servicemen." -(a)narendramodi, 17 March 2019

\subsection{Coding Process}

There were three coders assigned to qualitatively coding the tweets from the three politicians; a pair would be assigned to each set, and the third coder would arbitrate through the differences and provide a reconciled set. The coding itself was done in a binary manner - each theme would have a column, and the coder would mark a ' 1 ' if the theme was present, in check-box style coding. The coders themselves did several initial sets of tweets in order to get acclimated to the coding process, and would engage in discussions after these initial sets to clarify their questions regarding the themes. Upon a final discussion of the themes and universal agreement on their meanings, the coders then produced the finalized datasets. To ensure the integrity of our data, a weighted Cohen's Kappa assessed intercoder reliability for each pair of coders [42]. Partially following the methodology of Gonawela et al., the weighted kappa was accounted for tweets that contained limited agreement between the coders, as "less weight would be assigned to those partial agreements" [8] [42]. The subsequent Kappa for each pair of coders ranged from 0.67 to 0.79 across the politicians. Only the reconciled set is used for analysis.

\section{Findings}

We find that Modi is by far the most prolific and followed of the three politicians, and therefore has a larger footprint on Indian political social media, as seen in Table 1. However, it is important to note Gandhi's social media footprint has grown tremendously since 2017, evident in Gandhi's blossoming median retweet rates, seen in Figure 1.

We further summarize our findings in Tables 2 and 3 below. Table 2 represents the results of an independent samples t-test to relate means of retweets and favorites of tweets that were labeled (represented by " 1 ") as a certain category and those that were not (represented by " 0 "). We assessed the equality of variance through a Levene's test; if the variances were not equal, degrees were adjusted using WelchSatterthwaite method. Table 3 compares the proportion
Table 1: Follower counts, median retweets, and number of tweets for each set

\begin{tabular}{|c|c|c|c|}
\hline Handle & $\begin{array}{l}\text { Beginning of } \\
\text { Sample } \\
(1 / 1 / 2017)\end{array}$ & $\begin{array}{l}\text { End of } \\
\text { Sample } \\
(3 / 28 / 2019)\end{array}$ & $\begin{array}{l}\text { Number } \\
\text { of } \\
\text { Tweets }\end{array}$ \\
\hline @narendramodi & $\begin{array}{l}25,954,804 \\
\text { followers and } \\
1,862 \text { median } \\
\text { monthly } \\
\text { retweets }\end{array}$ & $\begin{array}{l}46,630,215 \\
\text { followers and } \\
5,271 \text { median } \\
\text { monthly } \\
\text { retweets }\end{array}$ & 7,645 \\
\hline @RahulGandhi & $\begin{array}{l}1,398,116 \\
\text { followers and } \\
1,100 \text { median } \\
\text { monthly } \\
\text { retweets }\end{array}$ & $\begin{array}{l}9,056,843 \\
\text { followers and } \\
10,238 \text { median } \\
\text { monthly } \\
\text { retweets }\end{array}$ & 1,107 \\
\hline @AmitShah & $\begin{array}{l}3,789,410 \\
\text { followers and } \\
412 \text { median } \\
\text { monthly } \\
\text { retweets }\end{array}$ & $\begin{array}{l}13,084,852 \\
\text { followers and } \\
3,150 \text { median } \\
\text { monthly } \\
\text { retweets }\end{array}$ & 2,604 \\
\hline
\end{tabular}

Figure 1: Median Retweets for the Politicians, January 2017 - March 2019

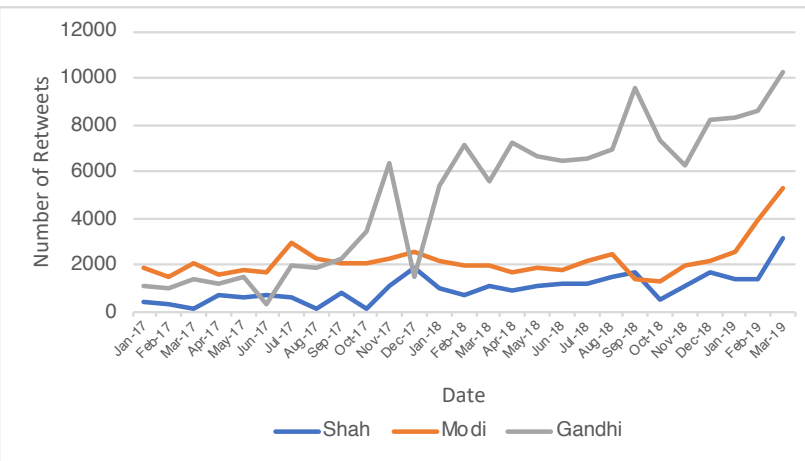

of tweets coded as certain categories for each political figure using a $\mathrm{z}$-test, and equal variance was assumed.

We found that all three politicians show significantly different retweets for negative tweets. While mean retweets and favorites are higher for Modi $(\mathrm{p}<0.01)$ and Gandhi $(\mathrm{p}<0.01)$, Shah has higher retweets $(p<0.01)$ but fewer mean favorites $(p<0.1)$.

\subsection{Criticism}

Gandhi used 'Criticism' considerably more $(=34.57 \%)$ than either Modi or Shah did, with more than a third of his tweets in the set containing the theme. In contrast, Modi dedicated only a very small proportion of his tweets $(=4.02 \%)$ to Criticisms, while Shah devoted only a bit more $(=10.06 \%)$, relative to the rest of his tweets. However, all three politicians showcased statistically significantly higher means of retweets and favorites for the category. Yet, delving deeper into the theme, we find that 'Criticisms' devoid of 'Insults' paint a slightly different picture, as mean 
Table 3: Z-score test comparing the proportions of all themes between the politicians

\begin{tabular}{l|c|c|c|}
\hline & \multicolumn{3}{|c|}{ Handle } \\
\hline Label & $@$ narendramodi & @RahulGandhi & @ AmitShah \\
\hline Criticism & $4 \% \mathrm{a}$ & $35 \% \%_{\mathrm{b}}$ & $10 \%_{\mathrm{c}}$ \\
\hline Insult & $3 \% \mathrm{a}$ & $22 \%_{\mathrm{b}}$ & $7 \%_{\mathrm{c}}$ \\
\hline Wordplay & $2 \% \mathrm{a}$ & $8 \%_{\mathrm{b}}$ & $2 \%_{\mathrm{a}}$ \\
\hline Humor \& & $0 \% \mathrm{a}$ & $11 \%_{\mathrm{b}}$ & $2 \% \mathrm{c}$ \\
Sarcasm & & $40 \% \%_{\mathrm{b}}$ & $35 \%_{\mathrm{c}}$ \\
\hline Regards & $30 \% \mathrm{a}$ & $\mathrm{a}$ & \\
\hline
\end{tabular}

Note: Subscript values that are different within each row represent statistically significant difference at the $p<0.05$ level

favorites for Gandhi's usage of non-insult criticisms is not significantly different $(\mathrm{p}=0.42, \mathrm{t}(1105)=-0.8043)$.

Much of Gandhi's use of 'Criticism' was largely targeted towards either Modi or the BJP, whereas there was a bit more diversity in the targets of both Modi and Shah, who not only attacked the Gandhi Dynasty and Congress, but also levied criticisms against other politicians such as Mamata Banerjee, leader of the All India Trinamool Congress Party in West Bengal. For example, we see this in the below tweet by Amit Shah:

The misgovernance of TMC and Left has ruined the great land of Bengal. A state which was so prosperous that it use to contribute about $27 \%$ of India's total Industrial production has now been brought down to a mere $3.3 \%$ during Mamata Didi's regime. https://t.co/eF2gAOkYVT" -@,AmitShah, 22 January 2019

Hence, we see the traits of a 'criticism' tweet, while noting that the theme itself is all-encompassing of negative sentiments; as seen with Shah's allegations against Banerjee's 'misgovernance'. Contextually, it is important that Ms. Banerjee was singled out for criticism by the party head, unlike a number of other regional leaders, since her home state of West Bengal was a major battleground for the party.

\subsection{Insult}

In terms of raw proportions, Gandhi's usage of 'Insults' $(=22.20 \%)$ outranked both Modi $(=2.62 \%)$ and Shah (=6.87\%) significantly. Yet, when we looked at 'Insults' as a subsection of 'Criticisms', we find that 'Insults' are the default attack style for all politicians, comprising around two-thirds of the 'Criticisms' for each. Moreover, insults for all politicians were significantly more popular in terms of mean retweets, seen most in Gandhi's insults. However, while insults were significantly more retweeted $(\mathrm{p}<0.01, \mathrm{t}(7643)=$ 5.1907 ) by Modi's followers, this was not replicated in 'favorites', as 'Insults' for Modi had no significant difference $(\mathrm{p}=0.31, \mathrm{t}(7643)=1.008)$ in 'favorites' solicited.

Both sides claim that regional oppositional figures create an atmosphere dangerous to their own sides, in essence using insults to levy accusations of mob-rule and murder. For example, take the two tweets by Amit Shah and Rahul Gandhi below:

"Soon Mamata didi will go out of power because in democracy a govt which perpetuates atrocities on its people doesn't last long. Under Mamata didi's watch more than 20 BJP karyakartas have been killed. The blood of these innocent karyakartas will not go in vain. https://t.co/AHb9nBKABQ" -- Amit Shah, 28 June 2018

"Anybody who speaks against the RSS/BJP is

Table 2: Independent samples t-tests comparing the means of retweets and favorites across the themes for all three politicians

\begin{tabular}{|c|c|c|c|c|c|c|c|}
\hline \multirow[t]{2}{*}{ Labels } & & \multicolumn{2}{|c|}{ @narendramodi } & \multicolumn{2}{|l|}{ @RahulGandhi } & \multicolumn{2}{|l|}{ @AmitShah } \\
\hline & Code & 1 & 0 & 1 & 0 & 1 & 0 \\
\hline \multirow{3}{*}{ Criticism } & Count & 307 & 7338 & 383 & 724 & 262 & 2342 \\
\hline & RT & $3726.987 * * *$ & $2609.120 * * *$ & $7319.175 * * *$ & 3314.765 *** & $2500.664 * * *$ & 1261.730 *** \\
\hline & Favorite & $13147.013^{* *}$ & $11583.245^{* *}$ & $19210.548 * * *$ & $11394.869 * * *$ & $7490.519^{* * * *}$ & $4719.311^{* * *}$ \\
\hline \multirow{3}{*}{$\begin{array}{l}\text { Non-Insult } \\
\text { Criticisms }\end{array}$} & Count & 107 & 7538 & 137 & 970 & 83 & 2521 \\
\hline & RT & $4061.551^{* *}$ & $2634.031^{* *}$ & $5284.819^{*}$ & $4618.300^{*}$ & $2058.831^{* * * *}$ & $1364.246^{* * *}$ \\
\hline & Favorite & $14571.701 * * *$ & $11604.512 * * *$ & 13211.094 & 14228.305 & $6454.096^{* *}$ & $4950.200 * *$ \\
\hline \multirow{3}{*}{ Insult } & Count & 200 & 7445 & 246 & 861 & 179 & 2425 \\
\hline & RT & $3547.995 * * *$ & $2629.995 * * *$ & $8452.321 * * *$ & $3630.523 * * *$ & $2705.536^{* * * *}$ & $1289.012 * * *$ \\
\hline & Favorite & 12384.805 & 11626.195 & $22550.581 * * *$ & $11685.971 * * *$ & $7971.095^{* * * *}$ & 4778.687 *** \\
\hline \multirow{3}{*}{ Wordplay } & Count & 126 & 7519 & 92 & 1015 & 54 & 2550 \\
\hline & RT & $3524.349 * * *$ & $2639.426 * * *$ & $8337.489 * * *$ & $4372.514 * * *$ & $2348.870^{* * *}$ & $1366.003 * * *$ \\
\hline & Favorite & $13840.968^{* *}$ & 11609.259 ** & $21540.043 * * *$ & $13425.990 * * *$ & $7327.926 * *$ & $4948.798 * *$ \\
\hline \multirow{3}{*}{$\begin{array}{l}\text { Humor \& } \\
\text { Sarcasm }\end{array}$} & Count & 29 & 7616 & 123 & 984 & 40 & 2564 \\
\hline & RT & $4976.138 * * *$ & $2645.168 * * *$ & $8775.797 * * *$ & $4192.813 * * *$ & $3378.100^{* * * *}$ & $1355.313^{* * * *}$ \\
\hline & Favorite & $17032.897 * *$ & $11625.529^{* *}$ & $22747.650 * * *$ & $13019.414 * * *$ & $9654.250^{* * * *}$ & $4925.496 * * *$ \\
\hline \multirow{3}{*}{ Regards } & Count & 2322 & 5323 & 447 & 660 & 921 & 1683 \\
\hline & RT & $2956.257 * * *$ & $2522.083 * * *$ & $3288.490 * * *$ & $5659.388 * * *$ & $932.515 * * *$ & $1634.759 * * *$ \\
\hline & Favorite & $13881.784 * * *$ & $10670.161 * * *$ & $11666.461 * * *$ & $15748.721 * * *$ & $3999.054 * * *$ & 5544.869 *** \\
\hline
\end{tabular}

Note: Significant difference by each mean is shown by: ${ }^{* \star}-p<0.01,{ }^{* *}-p<0.05,{ }^{*}-p<0.1$ 
attacked \&amp;even killed. They want to impose only one ideology which is against the nature of India" -- @ RahulGandhi, 6 September 2017

The BJP use of insults hinged on the Gandhi dynasty, and the 'control' they allegedly possess over the INC. Such insults contained references to corruption, and the notion that Congress politicians are 'anti' certain demographics, whether that's in assertions that Gandhi 'hates' the military, or supports casteism - drawing on Modi's own socio-economic background. This tweet by Modi outlines much of this:

"Congress imposed Emergency. Congress insults the Armed Forces. Congress goes on foreign soil and spreads lies about democratic processes. Congress misuses Article 356. Yet, they say Modi destroys institutions. How much do they lie? https://t.co/bz7hVBArzG" -- @ narendramodi, 7 February 2019

On the other hand, tweets later in Gandhi's set showcase a large amount of insults focusing on the 'Rafale Scandal', a military purchase by India from France's Dassault Aviation that elicited much controversy. Gandhi casts Modi as complicit, branding the scandal as 'Rafalegate' - akin to Richard Nixon's waterloo, with an implicit claim that Modi will face 'judgment' on Election Day. For example:

"PM removed the CBI Director to stop him from investigating Rafale. Mr 56 broke the law when he bypassed CJI \& LOP. Mr Modi, Rafale is a deadly aircraft with a superb radar. You can run, but you can't hide from It." -- @RahulGandhi, 24 October 2018

\subsection{Wordplay}

Usage of wordplay is relatively sparse in the tweets of $\operatorname{Modi}(=1.65 \%)$ and $\operatorname{Shah}(=2.07 \%)$, but is a bit more prominent with Gandhi $(=8.30 \%)$. Yet, the presence of wordplay was still significantly more popular in both the retweets and favorites of all three politicians.

Gandhi's usage of wordplay often hinged on giving nicknames to his opponents, especially as his tweets on the 'Rafale Scandal' intensified, as seen below:

"NoMo Jobs! The Fuhrer promised us $2 \mathrm{Cr}$ jobs a year. 5 years later, his leaked job creation report card reveals a National Disaster. Unemployment is at its highest in 45 yrs. $6.5 \mathrm{Cr}$ youth are jobless in 2017-18 alone. Time for NoMo2Go. \#HowsTheJobs https://t.co/nbX4iYmsiZ" -@RahulGandhi, 31 January 2019
We observe Gandhi making a series of puns off of Modi's name ("NoMo"), in addition to labeling Modi as 'The Fuhrer', comparing him to Hitler. Moreover, Gandhi has referred to Modi as "Mr. 56" in his tweets on Rafale, a pun on claims of Modi having a 56-inch chest, as a personal affront. This highlights the difficulty of conducting research on political tweets without contextual awareness.

\subsection{Humor and Sarcasm}

Humor and Sarcasm is another theme that is sparsely used by $\operatorname{Modi}(=0.38 \%)$, and relied upon by Gandhi $(=11.10 \%)$. Gandhi's use of the theme was significantly more popular. Shah only somewhat used the theme, but relative to his other tweets, it was rare $(=1.54 \%)$, yet statistically significant in popularity.

Both Shah and Gandhi consistently paired their humor and sarcasm with insulting rhetoric, using humor/sarcasm as a means to insult opponents. Notably, Gandhi seldom used the theme in 2017, only using it more from 2018 and on. Gandhi's usage of humor often involved him 'addressing' Modi, and using humorous rhetoric to implicate Modi in a scandal or frame him as a devious thief. For example:

"Mr 56 does $\bigcirc$ someone after all. 1. Must wear a suit 2. Must have $45,000 \mathrm{CR}$ debt 3 . Must have a TEN day old company. 4. Must never have made an aircraft in his life. Rewards of up to $\$ 4$ billion in "off set" contracts if you fulfil said criteria. https://t.co/243CSV1cep" -- @RahulGandhi, 25 July 2018

As we observe, Gandhi sarcastically claims that Modi loves Anil Ambani, an industrialist implicated in the Rafale aircraft deal scandal. This tweet is also multi-layered, as it alludes to Modi's lack of a spouse, and references specific details related to the case.

\subsection{Regards}

Tweets containing the positive attributes noted in 'Regards' were significantly more unpopular for Shah and Gandhi - while they were significantly more popular in retweets $(\mathrm{p}<0.01, \mathrm{t}(7643)=6.2269)$ and favorites $(\mathrm{p}<0.01, \mathrm{t}(7643)=10.6019)$ for Modi. By and large, the category is the largest theme for all politicians, showing that positive is used more than negative rhetoric ('Criticisms') by all politicians. A likely reason for why popularity is considerably lower for this theme in Gandhi and Shah's tweets is that both men often respond to individual accounts with 
gratitude for birthday wishes, and such strings of 'gratitude tweets' will number in the hundreds at times.

Aside from gratitude, many of the regards tweets contained greetings for varying festivals and days of recognition, condolences for deaths of public figures, or other tragedies. Notably, a large portion of Modi's regards tweets are in strings of tributes, either highlighting achievements of athletes or describing virtuous accomplishments by a set of people, whom Modi will often mention that he has met. For example:

It was a delight meeting Akash Malik, who won a Silver medal for India in Men's Recurve Individual Archery event at the 2018 Youth Olympic Games. His determination towards sports is praiseworthy. My best wishes for all his future endeavours. https://t.co/8QWKcPNv7w -- @narendramodi, 21 October 2018

\section{Discussion and Conclusion}

Our findings support Ott's assertion that Twitter is conducive to negative rhetoric, and in fact provides great benefits to those speakers [33]. Across the board, negative language was retweeted significantly more by followers of all three politicians, especially as we look at the popularity of insults. The large number of average retweets for insults only reinforces the idea that antagonism is prone to virality, moreso than positive messaging [35]. The finding that all three politicians devoted roughly two-thirds of the critical tweets to personal attacks only furthers Ott's argument that Twitter is conducive to 'coarseness'. Moreover, it's valuable to note that many of these insults took on the first-person - as the politicians themselves were levying the allegations, rather than a third-party voice.

Additionally, the nature of the insults by all three politicians subscribes closely to the standards of Edelman's 'Political Enemy' - namely in asserting that each politician's respective opponent was morally repugnant or working to undermine society [9]. For example, all three politicians continually assert that their opponents are destroying democracy, whether it pertains to Gandhi's casting of Modi as a Nixon-esque figure embroiled in corruption, or Modi's attacks on the 'dictatorial' nature of the Gandhi Dynasty's past by invoking either the Emergency Period or their dominance of the Congress Party. For both sides, the opponents are greedy for power, and are framed as doing anything they can to secure it. This is evident in the assertions by politicians on all sides, during any incident of party violence, that the leaders in charge, whether they be Chief Minister Mamata Banerjee or Modi himself, are murderers. Notably, Gandhi's thinly- veiled reference to Modi as "The Fuhrer" reinforces this. In essence, the opponent is comprehensively evil.

However, we do note that there are some key differences in terms of the styles of these insults. Notably, is the usage of humor by Gandhi in his insults (and the lack thereof by Modi and Shah), which corresponds directly with the Bakhtinian carnival [15] [16] . Ironically, despite Gandhi seemingly epitomizing a 'political elite', as heir to a longstanding political dynasty, his usage of humor and mockery makes him the outsider to his followers, as he aims to 'bring it' to the true 'political elite' in power - the BJP. His status as being in the opposition grants him the privilege of using humor in a carnivalesque manner. Badarneh's description of the ironic 'crowning' is used repeatedly by Gandhi, through references to Modi as "Supreme Leader" that are a lead-in to the disparagement of an action by Modi [17]. When Modi ran in 2014, as an opposition candidate, he was able to refer to Gandhi as 'Shahzada' - yet the incumbency has seemingly deprived Modi of the 'crowning' tool, since he now wears the crown due to him being prime minister.

This final point also highlights an important distinction between incumbents and challengers. Gandhi's aggression online can be seen from the view of outsider politics, where attacking the person who represents the state is a legitimate form of political discourse, but also at an individual level within the context of his own evolution. For years referred to derisively as 'pappu' ('little boy') through viral campaigns run by detractors, social media offered Gandhi a means to present an alternative narrative.

On the other hand, 2014's Modi, who vociferously used criticisms online and oft indulged in aggressive insults, maintained a statesmanly online presence during 2019. The high use of regards suggests the performance of benevolence, focusing on the positive in one's public missives. While this may not align with leaders like Donald Trump, it still offers an example of how social media can be a means for constantly reinventing a political brand. Prior research has shown that Modi's style has transformed from abrasive and aggressive to 'nicer' and more 'inclusive' [43] [8].

The recent results of the Indian General Elections qualify some of the findings. As a non-incumbent, Gandhi's proneness to attack substantially more than those in power is a default of sorts [31]. Gonawela et al.'s study on populist candidates, whose concepts this paper is rooted in, looked at four politicians whose antagonistic messaging was rewarded on Twitter, and also who won or did well in their respective elections; those findings do not parallel Gandhi's own electoral fortunes [8]. Modi's victory by a larger majority provides interesting questions regarding the true return of antagonistic messaging on Twitter and other social 
media platforms. This is an especially interesting direction for further research, as more candidates on both sides of the political aisle, including in the US, get more active, personalized, and negative on Twitter.

However, such qualifications do not take away from the importance of Twitter as a microphone for politicians to directly reach audiences. The fact that negative rhetoric is used on one of the largest 'directto-audience' platforms available is notable. Discussing the importance of Twitter as a microphone is invaluable to understand the future of political communication as social media grows, in addition to how it's used to express opinions, foster discourse, and manipulate minds, in this 'Age of Fake News'.

Our research shows that social media is integral to the creation of a politicians' brand, considerably more than it was during Obama's 2008 Campaign [19]. Social media was a means by which Gandhi and Modi 'reinvented' their political personalities. In the Trump Era, physical stump speeches are now replaced by 280 character micro-messages that have higher resonance among electorates, especially as these are shared by followers within their own networks. Our study fills the niche of research concerning the use of negative rhetoric by candidates themselves, rather than the public. The online rewards we observe on Twitter for antagonism, and the ease of network spread, are vital to understand as political polarization within national communities is explored. Social media is central to political communication - and the prevalence of negative messaging presents researchers questions as they aim to foster discourse on these platforms.

\section{References}

[1] Salvador, P., P. Salvador, P.C. Vivar, E. de Vera, R.B. Inocian, and R.C. Rosaroso, "Influence of Facebook to Voters' Political Practices." Asia Pacific Journal of Education, Arts and Sciences 4.1, 2017, pp. 15-23.

[2] Chagas-Bastos, F.H., "Political Realignment in Brazil: Jair Bolsonaro and the Right Turn." Revista de Estudios Sociales 69, 2019, pp. 92-100.

[3] Francia, P.L. "Free media and Twitter in the 2016 presidential election: The unconventional campaign of Donald Trump." Social Science Computer Review 36.4, 2018, pp. 440-455.

[4] Gervais, B.T., H.K. Evans, and A. Russell. "Fear and Loathing on Twitter: Exploring Negative Rhetoric in Tweets During the 2018 Midterm Election." The Roads to Congress 2018. Palgrave Macmillan, Cham, 2019.

[5] Pal, J., L. Bozarth, "Is Tweeting in Indian Languages Helping Politicians Widen Their Reach?" Economic \& Political Weekly, 53(25), 2018.
[6] Jaffrelot, C., "The Modi-centric BJP 2014 election campaign: New techniques and old tactics," Contemporary South Asia 23.2, 2015, pp. 151-166.

[7] Alashri, S., S. S. Kandala, V. Bajaj, E. Parriott, Y. Awazu, \& K. C. Desouza, "The 2016 US Presidential Election on Facebook: an exploratory analysis of sentiments." Proceedings of the 51st Hawaii International Conference on System Sciences, 2018.

[8] Gonawela, A., J. Pal, U. Thawani, E. Van Der Vlugt, W. Out, P. Chandra, "Speaking their Mind: Populist Style and Antagonistic Messaging in the Tweets of Donald Trump, Narendra Modi, Nigel Farage, and Geert Wilders." Computer Supported Cooperative Work (CSCW) 27.3-6, 2018, pp. 293326.

[9] Edelman, M., Constructing the Political Spectacle. University of Chicago Press, 1988.

[10] De la Torre, C., "Populism and democracy: political discourses and cultures in contemporary Ecuador." Latin American Perspectives 24.3, 1997, pp. 12-24.

[11] Potts, L., "Problem Definition and Causal Attribution During the Republican National Convention: How\# MAGA Discourse on Twitter Framed America's Problems and the People Responsible,” Diss. Purdue University, 2017.

[12] Gervais, B.T. "Rousing the Partisan Combatant: Elite Incivility, Anger, and Antideliberative Attitudes." Political Psychology, 2018.

[13] Gervais, B.T. "More than mimicry? The role of anger in uncivil reactions to elite political incivility." International Journal of Public Opinion Research 29.3, 2016, pp. 384-405.

[14] Anderson, A.A., D. Brossard, D.A. Scheufele, M.A Xenos, and P. Ladwig, "The "nasty effect:" Online incivility and risk perceptions of emerging technologies." Journal of Computer-Mediated Communication 19.3, 2014, pp. 373387.

[15] Bakhtin, M., Problems of Dostoevsky's poetics. Vol. 8. U of Minnesota Press, 2013.

[16] Janack, J. A. "The Rhetoric of "The Body:" Jesse Ventura and Bakhtin's Carnival." Communication Studies 57.2, 2006, pp. 197-214.

[17] Badarneh, M.A., "Carnivalesque politics: A Bakhtinian case study of contemporary Arab political humor," 2011, pp. 305-327.

[18] Lundgaard, D., L. Razmerita, and C. Tan, "Emergent Collaboration on Twitter: A Case Study of the\# BlackLivesMatter Movement," Proceedings of the 51st Hawaii International Conference on System Sciences, 2018. 
[19] Zavattaro, S.M. "Brand Obama: The implications of a branded president." Administrative Theory \& Praxis 32.1, 2010, pp. 123-128.

[20] Davis, R., J.C. Baumgartner, P.L. Francia, \& J.S. Morris, "The Internet in US election campaigns." Routledge handbook of Internet politics. Routledge, 2008, pp. 29-40.

[21] Towner, T.L., and D.A. Dulio. "New media and political marketing in the United States: 2012 and beyond." Journal of Political Marketing 11.1-2, 2012, pp. 95-119.

[22] Metzgar, E., and A. Maruggi. "Social media and the 2008 US presidential election." Journal of New Communications Research 4.1, 2009.

[23] Jungherr, A., "Twitter use in election campaigns: A systematic literature review." Journal of information technology \& politics 13.1, 2016, pp. 72-91.

[24] Pal, J., and A. Gonawela. "Political social media in the global South." Conference on e-Business, e-Services and eSociety. Springer, Cham, 2016.

[25] Zamora-Medina, R., and C. Zurutuza-Muñoz. "Campaigning on Twitter: Towards the "personal style" campaign to activate the political engagement during the 2011 Spanish general elections," 2014.

[26] Schweitzer, E.J.. "The mediatization of e-campaigning: Evidence from German Party Websites in State, National, and European Parliamentary Elections 2002-2009." Journal of Computer-Mediated Communication 17.3, 2012, pp. 283302.

[27] Bode, L., and K.E. Dalrymple. "Politics in 140 characters or less: Campaign communication, network interaction, and political participation on Twitter." Journal of Political Marketing 15.4, 2016, pp. 311-332.

[28] Posegga, O., and A. Jungherr. "Characterizing Political Talk on Twitter: A Comparison Between Public Agenda, Media Agendas, and the Twitter Agenda with Regard to Topics and Dynamics." Proceedings of the 52nd Hawaii International Conference on System Sciences, 2019.

[29] Meeks, L., "Gendered styles, gendered differences: Candidates' use of personalization and interactivity on Twitter." Journal of Information Technology \& Politics 13.4, 2016, pp. 295-310.

[30] Ceccobelli, D., "Not every day is Election Day: a comparative analysis of eighteen election campaigns on Facebook." Journal of Information Technology \& Politics 15.2, 2018, pp.122-141.
[31] Borah, P., "Political Facebook use: Campaign strategies used in 2008 and 2012 presidential elections." Journal of Information Technology \& Politics 13.4, 2016, pp. 326-338.

[32] Benoit, W. L. Communication in political campaigns. Vol. 11. Peter Lang, 2007.

[33] Ott, B.L. "The age of Twitter: Donald J. Trump and the politics of debasement." Critical studies in media communication $34.1,2017$, pp. 59-68.

[34] Thelwall, M., K. Buckley, and G. Paltoglou, "Sentiment in Twitter events," Journal of the American Society for Information Science and Technology, 62(2), 2011, pp. 40618.

[35] Rossini, P., J. Stromer-Galley, K. Kenski, J. Hemsley, F. Zhang, and B. Dobreski, "The relationship between race competitiveness, standing in the polls, and social media communication strategies during the 2014 US gubernatorial campaigns," Journal of Information Technology \& Politics 15.3, 2018, pp. 245-261.

[36] Stromer-Galley, J., Presidential campaigning in the Internet age. Oxford University Press, 2014.

[37] Kreiss, D., Taking our country back: The crafting of networked politics from Howard Dean to Barack Obama, Oxford University Press, Oxford, UK, 2012.

[38] Pal, J. "Banalities turned viral: Narendra Modi and the political tweet." Television \& New Media 16.4, 2015, pp. 378-387.

[39] Baishya, A. "Selfies|\# NaMo: The political work of the selfie in the 2014 Indian general elections." International Journal of Communication 9, 2015, pp. 1686-1700.

[40] Dwivedi, Y.K., and K. K. Kapoor. "Metamorphosis of Indian electoral campaigns: Modi's social media experiment." Int. J. Indian Cult. Bus. Manag, 11.4, 2015, pp. 496-516.

[41] Pal, J., P. Chandra, P. Chirumamilla, V. Kameswaran, A. Gonawela, U. Thawani, and P. Dasgupta, "Innuendo as Outreach:@ narendramodi and the Use of Political Irony on Twitter." International Journal of Communication, 11, 2017, pp. 4197-4218.

[42] Cohen, J., "Weighted kappa: Nominal scale agreement provision for scaled disagreement or partial credit." Psychological bulletin 70.4,1968, pp. 213-220.

[43] Pal, J., D. Mistree, and T. Madhani, "A Friendly Neighborhood Hindu." CeDEM Asia 2018: Proceedings of the International Conference for E-Democracy and Open Government; Japan 2018. Edition Donau-Universität Krems, 2018. 